\title{
Contagion in International Bond Markets During the Russian and the LTCM Crises
}

\author{
Mardi Dungey ${ }^{* \%}$, Renée Fry ${ }^{*+}$, Brenda González-Hermosillo^, and Vance Martin ${ }^{\#}$
}

September 2002

\begin{abstract}
The Russian and LTCM crises of August-September 1998 represent an unusual period of volatility in international bond markets with bond spreads increasing dramatically across the globe. Using a latent factor model and a new data set spanning markets across Asia, Europe and the Americas, we quantify the contribution of contagion to the spread of these crises. Contagion accounts for less than 17 percent of total volatility, with the main effects due to the Russian crisis. Both developing and developed markets experienced contagion from both crises. The relatively larger contagion experienced in developing markets is a reflection of their higher volatility.
\end{abstract}

JEL Classification Numbers: C33, E44, F34

Keywords: Financial Crises, Contagion, Spillovers, Russia, LTCM, latent factor model Authors' E-Mail Address: mardi.dungey@anu.edu.au;renee.fry@anu.edu.au;

bgonzalez@imf.org; vance@,unimelb.edu.au

\footnotetext{
*Australian National University, ${ }^{\%}$ CERF Cambridge University, ${ }^{+}$Queensland University of Technology, International Monetary Fund and ${ }^{\#}$ University of Melbourne. Part of the research for this paper was undertaken when Mardi Dungey was a visiting scholar at the IMF Institute. Mardi Dungey and Vance Martin acknowledge funding from ARC grant no. A00001350. The authors are grateful to John Creedy, Charles Goodhart, Leslie Hull, Takishito Ito, José Lopez, Michael McAleer and Reza Vaez-Zadeh for helpful discussions. The authors also acknowledge useful suggestions by seminar participants at: the Third Joint Central Bank Research Conference on Risk Measurement held at BIS, Basel, March 2002; the IMF; the Australian National University; University of Otago; University of Western Australia; Queensland University of Technology, the German and Swiss Associations of Investment Professionals; the Econometric Society of Australasia Meeting 2002; and the 57 th European Meeting of the Econometric Society. The views expressed in this paper are those of the authors and do not necessarily represent those of the International Monetary Fund.
} 
Since the mid-1990s, international financial markets have experienced several episodes of distress. During these crises, financial market participants have been concerned about the possibility that a crisis will spillover and lead to extreme volatility elsewhere in the world. The international spillover effects of some recent financial crises (e.g., the Mexican and Asian crises) appear to have been limited to other emerging markets or region(s). However, during the Russian/LTCM crises of August-September 1998, increased financial volatility was widespread across industrial and emerging countries. As events unfolded, the period of turmoil in global financial markets following the Russian default and the LTCM nearcollapse was relatively short, spanning only a few weeks, possibly due to the aggressive easing of monetary policy undertaken by the U.S. Federal Reserve between September and November 1998. Nonetheless, the effects of the 1998 crises were felt dramatically across global financial markets. The Bank of International Settlements' (1999) survey of market participants characterised the Russian bond default and the subsequent near-collapse of LTCM as "the worst crisis" in recent times.

This paper examines the transmission of the Russian and LTCM shocks to other countries. In particular, the focus is on the spreads between long-term soverign bonds issued in international markets by emerging economies, and long-term corporate bonds issued in advanced economies, vis-à-vis comparable risk-free benchmarks. These spreads or 'premiums' reached extraordinarily high levels in both developing and advanced economies during this period. Investors switched to highly liquid assets, demanding sharply higher premiums even for relatively low risk securities with less liquidity (for example, spreads between the 29-year U.S. Treasury bond and the more liquid 'on-the-run' 30-year bond reached historically high levels).

Most analyses of recent financial crises have focused on currency, banking or equity markets. There is little by the way of empirical literature on the spread of crises through the international bond markets. This is partly because bond markets in many developing 
countries have lacked liquidity, and because a consistent and comprehensive historical database on bond spreads is difficult to construct for the early periods. In addition, bond markets are found to be relatively stable during the Asian crisis compared with equity and currency markets. One of the advantages of examining bond spreads is that they reflect the risk premium that investors assign to prospective borrowers, either because of the perceived creditworthiness of borrowers or due to the willingness of lenders to take on risk. Of course, bond spreads also respond to the degree of liquidity in the market, although all of these factors seem to be entangled during crisis episodes. One interpretation of examining the effects of the Russian default and the LTCM crisis separately is that the former affected credit risk concerns, while the latter worked as a global liquidity shock.

This study attempts to shed light on several questions. Is the common increase in the volatility of bond market spreads a reflection of the long run relationships between economies, or was it the spillover of events from Russia and the U.S. to the other economies that is unanticipated, and therefore "contagion"? Is there evidence that the Russian crisis affected only emerging markets while the LTCM problems mainly affected matured markets, as suggested by the Bank for International Settlements (1999)? And relatedly, does the data show that developing markets are more likely to be affected by contagion than developed markets, as maintained, for example, by Kee-Hong Bae, G. Andrew Karyoli and Rene M. Stulz (2000) for equity markets?

We examine the daily behavior of bond spreads for 12 countries from several regions in the world: Argentina, Brazil and Mexico in Latin America; Indonesia, Korea and Thailand in Asia; Bulgaria, Poland and Russia in Eastern Europe; and the Netherlands, the U.K. and the U.S. as representative industrial countries in Europe and North America. The period of study encompasses February to end-December 1998. 
Specifically, a latent factor model of the spreads in the bond market is developed to examine the effects of unanticipated movements in the Russian and U.S. markets on other countries around the world. ${ }^{1}$ The bond spreads are decomposed into a set of latent factors, identified as common shocks and country-specific shocks, analagous to the systemic and idiosyncratic shocks of the finance literature. The origins of the model can be found in papers such as Frank X. Diebold and Marc Nerlove (1989) and Ronald Mahieu and Peter Schotman (1994). More recently, Mardi Dungey, Vance L. Martin and Adrian R. Pagan (2000) demonstrate how this type of model can be identified and estimated using indirect estimation techniques. We adopt a similar approach and introduce effects of the transmission of unanticipated country-specific shocks to other countries. In common with a substantial part of the literature, this effect is referred to as contagion; see for example Jeffrey Sachs, Aaron Tornell and Andrés Velasco (1996), Paul Masson (1999a,b,c), Dornbusch, Park and Claessens (2000) and Pericoli and Sbracia (2001).

The results show that there are discernible contagion effects from the Russian crisis to other markets. In contrast, global contagion effects from the LTCM near-collapse appear to be more limited. However, the absence of a larger contagion effect from the LTCM crisis may reflect its short duration as the Fed acted to contain a potential credit crunch. The evidence also suggests that while the U.S. experienced some contagion from Russia, contagion from the LTCM to Russia was very small.

In proportionate terms, contagion effects from Russia were particularly substantial for the Netherlands, Brazil, Bulgaria and Thailand. Countries relatively unaffected by contagion included the U.K., Indonesia, Mexico and Argentina. The overall results suggest that

\footnotetext{
${ }^{1}$ The advantage of this technique is that it is possible to identify and quantify these effects without resorting to ad hoc identification of the pertinent fundamentals. Examples of papers which consider particular fundamentals and discuss this problem are Barry Eichengreen, Andrew K. Rose and Charles Wyplosz (1996), Reuven Glick and Andrew K. Rose (1999), Kirsten Forbes and Roberto Rigobon (2002).
} 
contagion may be of importance not just to developing countries, but also to developed economies. Interestingly, Brazil was one of the countries most affected by contagion from Russia just prior to its crisis that unfolded in January 1999.

The remainder of this paper is organized as follows. Section I reviews the background of events and the stylized facts of the data, followed by a discussion of the data characteristics in Section II. A model of contagion is described in Section III, and is then related to the existing literature on contagion in Section IV. The estimation method is discussed in Section V followed by the empirical results in Section VI. Section VII concludes.

\section{BACKGROUND OF EVENTS AND STYLIZED FACTS}

During the Asian crisis, the turmoil which began with the devaluation of the Thai baht in July 1997 quickly precipitated declines in currencies and equities in the region and in other developing markets. However, the effects on the risk premia of the international bonds issued by emerging countries were rather limited. Apart from the relatively short period of turmoil in global financial markets resulting from the speculative attack on Hong Kong on October 27,1997 , bond spreads were relatively stable in non-Asian countries during the second half of 1997 (see Figure 1).

After a period of relative calm in international bond markets during the first part of 1998, Russia announced a de facto devaluation by widening the trading band of the ruble on August 17, 1998. Russia also declared its intention to restructure all official debt obligations falling due to the end of 1999 and imposed a 90-day moratorium on the repayment of private external debt. ${ }^{2}$ The Russian default appears to have led to a reassessment of credit risks

\footnotetext{
${ }^{2}$ Homi Kharas, Brian Pinto and Sergei Ulatov (2001) provide a discussion of the Russian crisis.
} 
Figure 1. Bond Spreads, January 1997-May $1999^{1}$ (basis points)
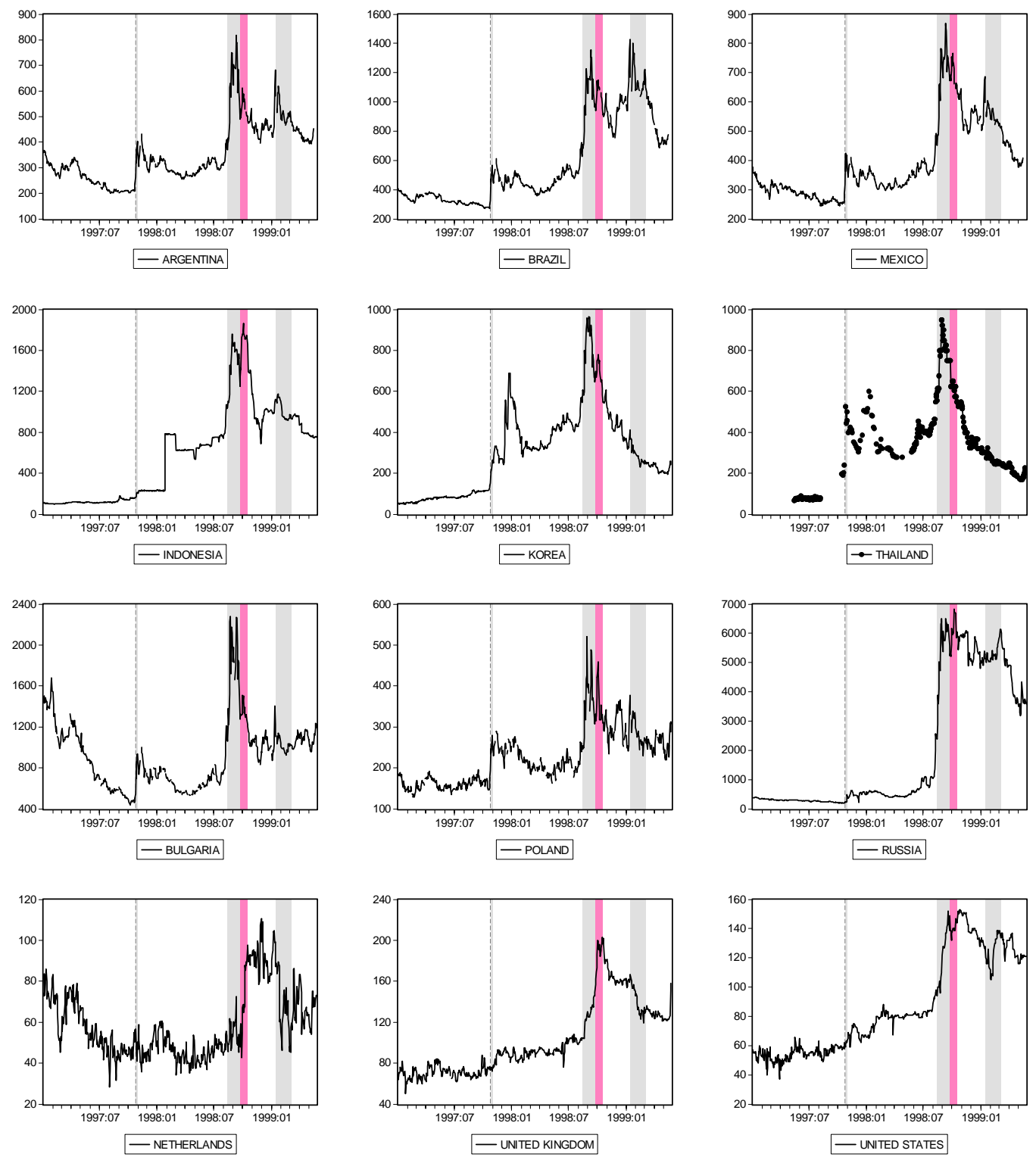

\footnotetext{
${ }^{1}$ The shaded areas refer to episodes of crisis in international bond markets: the Hong Kong speculative attack on October 27, 1997; the Russian bond default on August 17, 1998; the bailout of LTCM on September 23, 1998; the inter-FOMC Fed interest rate cut on October 15, 1998, which signaled the beginning of the "end" of the LTCM crisis; and the Brazilian effective devaluation on January 13, 1999 followed by several weeks of internal turmoil at the central bank. Data Sources: U.S. Federal Reserve, Bloomberg, Scotia Capital and Credit Swiss First Boston.
} 
Figure 2. Bond Spreads, January 1998-December $1998{ }^{1}$ (basis points)
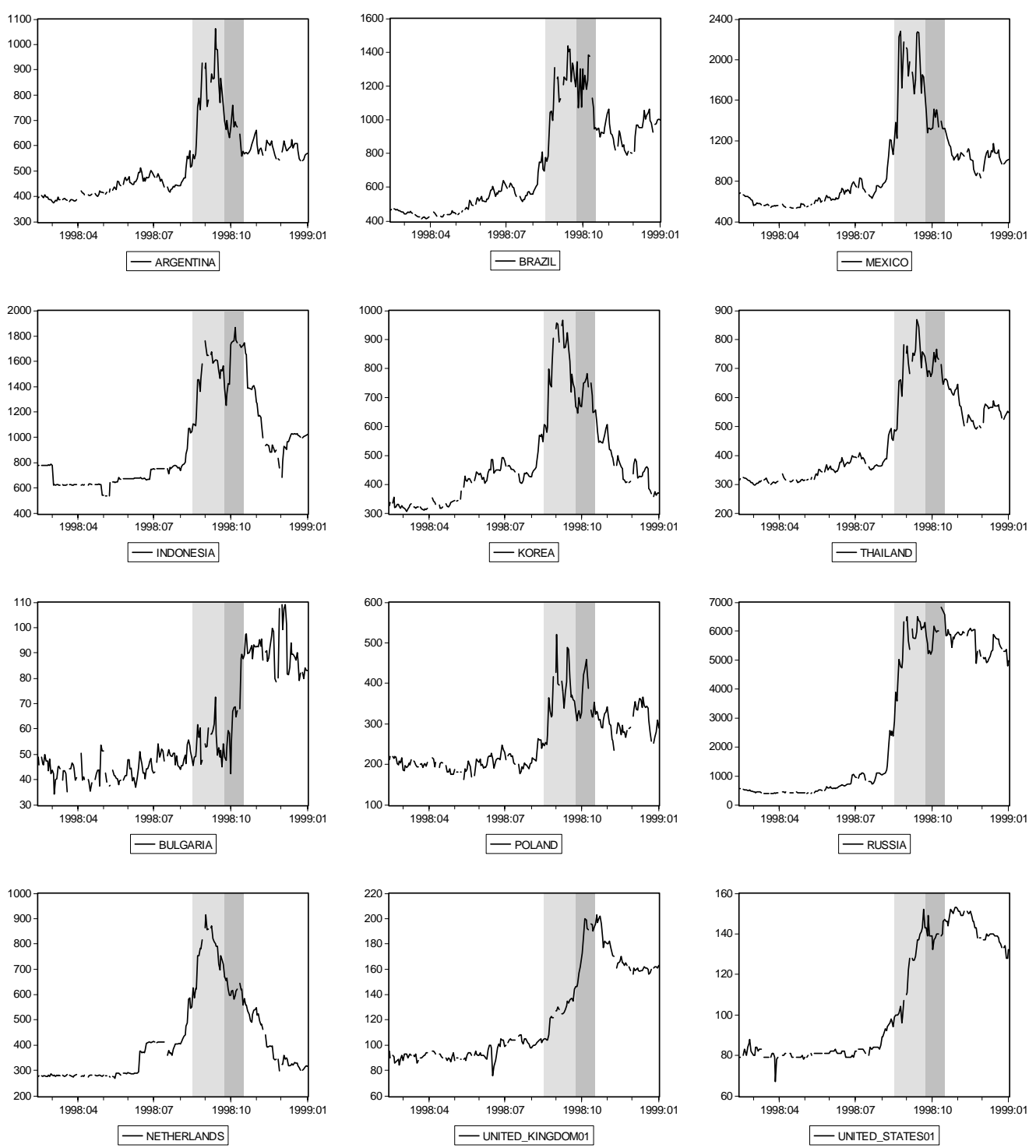

1 The shaded areas refer to episodes of crisis in international bond markets during this period: the Russian bond default on August 17, 1998; the bailout of LTCM on September 23, 1998; and the inter-FOMC Fed interest rate cut on October 15, 1998 which signaled the beginning of the "end" of the LTCM crisis. Data Sources: U.S. Federal Reserve, Bloomberg, Scotia Capital and Credit Swiss First Boston. 
across global financial markets, evidenced by large jumps on the bond spreads of a number of emerging markets and also in advanced economies (see Figures 1-2).

A few weeks after the Russian crisis was unveiled, news reached financial markets on September 23, 1998 about the financial plan to rescue LTCM, one of the largest U.S. hedge funds. LTCM is reported to have invested on the basis of 'normal' volatilities and spreads between closely related securities, some of which changed in the aftermath of the Russian crisis. Philippe Jorion (2000) documents that from end-December 1997 to the end of August 1998, LTCM lost more than 50 percent of its capital, and increased its assets-to-capital ratio from 28-1 to 55-1. The potential effect of LTCM, and other large hedge fund collapses, prompted the New York Federal Reserve to organised a bailout of LTCM by encouraging 14 banks to invest in the hedge fund.

During this period of extreme volatility, the U.S. Federal Reserve cut interest rates aggressively in three steps between September 29 and November 17, 1998. One of these moves was a surprise inter-FOMC meeting cut on October 15 which, according to market participants surveyed in Bank for International Settlements (1999), signaled the beginning of the abatement of financial constraints. ${ }^{3}$ The sharp easing in U.S. monetary policy was in part motivated by growing concerns that the U.S. economy was on the verge of experiencing a liquidity crash as corporate bond spreads in the U.S., and in other countries, had risen to exceptionally high levels, increasing the cost of financing for corporations.

3 This otherwise arbitrary "end" to the crisis of 1998, is supported by the findings of Manmohan Kumar and Avinash Persaud (2001). 
Informal examination of the data for the second half of 1998 (Figure 2) suggests that the Russian crisis had a substantial impact on all countries examined, both in advanced economies and emerging markets. The LTCM shock also appears to have had an impact on all the countries, with a relatively smaller hump experienced by most emerging countries relative to the effect of the Russian shock. The data seem to suggest that the Russian and the LTCM shocks were reinforcing in their effects on other financial markets since practically all markets experienced two jumps in their spreads: one following the Russian default (the first band in figure 2) and another one following the announcement of the LTCM financial problems (the second band in figure 2). Similarly, the fact that corporate bond spreads began to rise in the U.S. following the Russian crisis and that the Russian sovereign spread rose even further in the aftermath of the LTCM crisis suggests that these two events may not have been independent.

Unlike other recent financial crises, the shocks during August-September 1998 seem to have been transmitted across countries with little in common-including countries that do not fit traditional explanations of contagion based on trade links, competitive devaluation or regional effects as suggested in the taxonomies of contagion by Julia Lowell, Richard Neu and Daochi Tong (1998) and Morris Goldstein (1998). The crisis of 1998 affected countries as diverse as Russia and Brazil, and spanned emerging and advanced markets. Disentangling the crisis of 1998 is particularly complex because of its relative brevity and the fact that two distinct shocks occurred within weeks of each other. 


\section{The DATA AND SAMPle}

Daily data for twelve countries were collected for February to December 1998 (Mexico, Argentina, Brazil, Indonesia, Korea, Thailand, Bulgaria, Poland, Russia, the Netherlands, the U.K. and the U.S.). This sample period allows our estimation to incorporate a clear 'precrisis' period and the two crisis events of the Russian bond default and the LTCM neardefault.

The data represent the spread of long-term debt over the appropriate risk-free yield for each country (see Appendix I for source descriptions, definitions and details). We label this spread as the 'premium' while recognizing that it does in fact reflect a myriad of factors, including the liquidity premium and the term structure of the yield curve. The choice of the risk-free rate was specific to each long-term bond. In the case of emerging countries, sovereign bonds were issued in U.S. dollars and hence the spread is calculated against the comparable maturity-matched U.S. Treasury bond rate. Where possible, the bonds selected for emerging markets were sovereign issues to reflect the true cost of new foreign capital - the exceptions were Poland and Bulgaria which are represented by Brady bonds. In the case of the advanced markets, which are able to issue international bonds in domestic currency, BBB investment grade corporate bonds were compared to the corresponding risk-free Treasury bond in each country.

\footnotetext{
${ }^{4}$ Below-investment grade corporate issues experienced even bigger jumps in their spreads and in volatility. However, data limitations restricted the study to investment grade bonds.
} 
The statistical characteristics of the data are summarised as follows, with full details given in Appendix II. The rise in spreads over the period is approximated by a unit root, as the corresponding risk free rates remained relatively constant. Both larger means and absolute movements are evident in the premiums of developing markets compared to the industrialized countries. The data display non-normality, and fitting integrated univariate GARCH $(1,1)$ models to the changes in the premiums suggests that there is a common timevarying volatility structure underlying the data. This feature of the structure is exploited in the model described in the following section.

\section{A FACTOR Model OF THE "Premium"}

Volatility in the premiums of each country is hypothesized to be influenced by events that are country-specific and events that are common to all economies. However, it is difficult to ascertain both the timing and nature of these events. In the existing literature, contagion is tested conditioned on controlling for events chosen by the researcher after the observed financial crises, for example the work of Barry Eichengreen, Andrew Rose and Charles Wyplosz (1995, 1996), Sachs, Tornell and Velasco (1996), and Reuven Glick and Andrew Rose (1999) follows this approach. The economic indicators chosen in this way are often statistically insignificant, and it is difficult to know whether they are the 'correct' choice even ex-post. A desirable alternative, noted by authors such as Michael Dooley (2000) and Sebastian Edwards (2000), is to use a modelling specification which does not require the choice of specific indicators with which to associate the crises, that is to use latent factors.

Latent factor models have been specified for a number of markets. The majority of the existing empirical work has focused on currency and equity markets, such as represented in 
Diebold and Nerlove (1989), Victor Ng, Robert Engle and Michael Rothschild (1992), Mahieu and Schotman (1994), and Mervyn King, Enrique Sentana and Sushil Wadhwani (1994). Empirical work on interest rates is rather less extensive. Allan Gregory and David Watts (1995) explore long bond yields across countries, while Dungey, Martin and Pagan (2000) apply a latent factor model to the spreads between individual country bonds and the US bond. ${ }^{5}$

The basic model of the bond market adopted in this paper is similar to that specified in Forbes and Rigobon (2002) and King, Sentana and Wadhini (1994) for equity markets. Letting $r_{i, t}$ be the interest rate on the bond in country $i$, the interest rate is determined by a risk-free rate of interest, $r f_{i, t}$, a world factor, $W_{t}$ and a time-varying country-specific factor $f_{i, t}$

$$
r_{i, t}=r f_{i, t}+\lambda_{i} W_{t}+\phi_{i} f_{i, t}, \quad i=1 \ldots n
$$

The loadings on these world and country-specific factors are given by the parameters $\lambda_{i}$ and $\phi_{i}$ respectively. The common factor, $W_{t}$, affects the premiums in all countries, but with a differing parameter in each case.

Regional effects are potentially important in this data, as evidenced by the common regional GARCH characteristics of the previous section. Regional effects have been posited to be

\footnotetext{
${ }^{5}$ A similar class of models has recently been adopted by Ayhan M. Kose, Chris Otrok and Charles H. Whiteman in studying business cycles.
} 
important in the spread of crises, for example in the work of Graciela Kaminsky and Carmen Reinhart (2002). To incorporate these regional effects, equation (2) is extended as follows:

$$
r_{i, t}=r f_{i, t}+\lambda_{i} W_{t}+\phi_{i} f_{i, t}+\gamma_{\mathrm{i}} \mathrm{R}_{\mathrm{k}, \mathrm{t}}, \quad i=1, \ldots, n, k=1, \ldots, K
$$

where $R_{k, t}$ is a time-varying regional factor. Three economic regions are specified in the model, implying three regional factors, $K=3$. The first is a regional factor common to Latin America (Argentina, Brazil and Mexico) and denoted $\mathrm{R}_{\mathrm{Lat}, \mathrm{t}}$. The second is a regional factor common to the Asian economies (Indonesia, Korea and Thailand), denoted $\mathrm{R}_{\mathrm{As}, \mathrm{t}}$ whilst the third regional factor of Eastern Europe (Bulgaria, Poland and Russia) is denoted $R_{\text {Eur,t. No }}$ regional factor is included for the industrialized countries comprising the U.S., the U.K. and the Netherlands. Defining the premium to be $P_{i, t}=r_{i, t}-r f_{i, t}$, the model without contagion is specified as

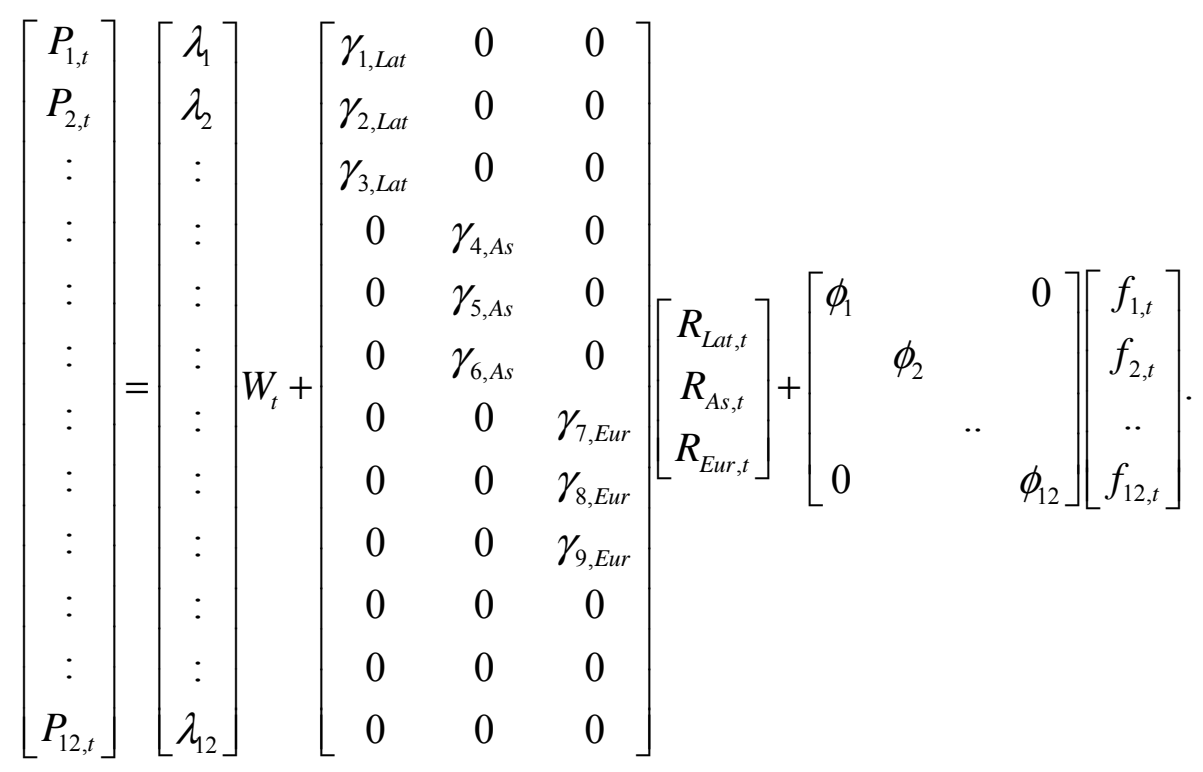


To incorporate the large movements in the premia over the sample period identified in Section II, the common factor is specified as integrated of order one

$$
W_{t}=W_{t-1}+\eta_{t},
$$

where $\eta_{\mathrm{t}}$ is a stationary disturbance term. The regional factors in (3) are also specified as integrated processes of order one

$$
R_{k, t}=R_{k, t-1}+v_{k, t} \text {, where } k=\text { Lat, As, Eur, }
$$

where $v_{k, t}$ are stationary disturbance terms. In addition, equation (3) shows that each premium has a unique idiosyncratic error, or country-specific factor, $f_{i, t}$. To complete the specification of the non-contagion model, the disturbance processes are assumed to be distributed as

$$
\eta_{t}, v_{\text {Lat }, t}, v_{A s, t}, v_{E u r, t}, f_{1, t}, f_{2, t} \ldots f_{12, t} \sim N\left(0, H_{t}\right)
$$

where in general $\mathrm{H}_{t}$ is a 16-variate system of independent GARCH processes with unit unconditional variances. Here we restrict the GARCH to the world factor, following the preliminary GARCH results of the previous section, which showed a high degree of commonality amongst the conditional variance structure of the premia. ${ }^{6}$

To allow for contagion, the effects of unanticipated shocks from other countries on the premium in country $i$ are incorporated by augmenting (3). The augmented system is shown in equation (7). An unanticipated shock from country $j$ is given by the effect of the $f_{j, t}$ on the ith equation with loading $\delta_{i, j}$. There are no own effects, that is $\delta_{i, j}=0$ when $i=j$.

\footnotetext{
${ }^{6}$ The three regional factors were also assumed to exhibit GARCH processes, but were found to be statistically insignificant.
} 


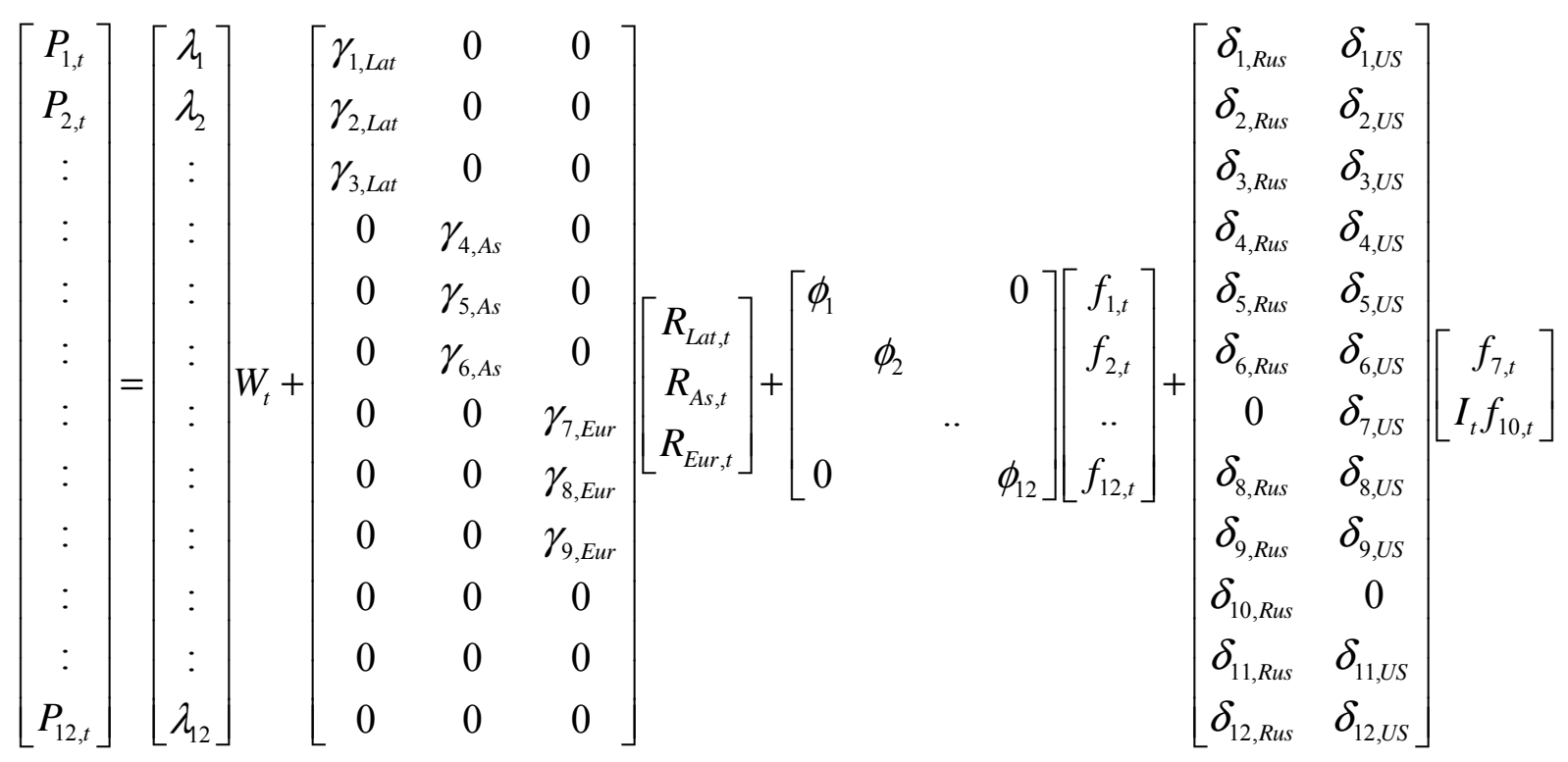

Our interest is in the effects of contagion from the Russian shock (as an international credit risk shock), which is represented by the impact of $f_{7, t}$ on the other premiums in the model, and the LTCM crisis (as an international liquidity shock), represented by the impact of $f_{10, t}$. The dominance of U.S. financial markets make it difficult to argue that U.S. based shocks over the whole period will represent only the LTCM crisis. To isolate the impact of the LTCM period, the U.S. country-specific factor, $f_{10, t}$ in (7) is preceded by an indicator variable I. This is a binary dummy, which takes the value of 1 for the period of the LTCM shock and 0 for the non-LTCM crisis period. ${ }^{7}$

\footnotetext{
${ }^{7}$ In Dungey, Fry, Gonzalez-Hermosillo and Martin (2002), the indicator variable, I, was set to 1 for the entire period - the influence of the US economy in global markets means that the impact of the LTCM shock was somewhat overstated.
} 
A useful way of examining the results from estimating a model such as (7) is to consider the contribution that each factor makes to total volatility in the movement of the premium of each country. As the factors are independent, the total variance of the change in the premiums for each economy can be conveniently decomposed as

$$
\operatorname{Var}\left(\Delta P_{i, t}\right)=\lambda_{i}^{2}+\gamma_{i}^{2}+2 \delta_{i, \text { Rus }}^{2}+2 \delta_{i, U S}^{2}+2 \phi_{i}^{2}
$$

The results of interest are then given as the proportion of total volatility in the changes in the premium for country $i$ due to the:

(i) contribution of the world factor

$$
\frac{\lambda_{i}^{2}}{\operatorname{Var}\left(\Delta P_{i}\right)}
$$

(ii) contribution of the regional factor

$$
\frac{\gamma_{i}^{2}}{\operatorname{Var}\left(\Delta P_{i}\right)}
$$

(iii) contribution of country-specific factor

$$
\frac{2 \phi_{i}^{2}}{\operatorname{Var}\left(\Delta P_{i}\right)}
$$

(iv) contribution of contagion from Russia

$$
\frac{2 \delta_{i, R u s}^{2}}{\operatorname{Var}\left(\Delta P_{i}\right)}
$$

(v) contribution of contagion from the U.S.

$$
\frac{2 \delta_{i, U S}^{2}}{\operatorname{Var}\left(\Delta P_{i}\right)}
$$

\section{RELATIONSHIP WITH EXISTING LITERATURE}

The models estimated in this paper decompose volatility in the spread between long bonds and the appropriate 'risk-free' rate, or the premium, for a variety of economies into a set of latent factors. In common with a substantial portion of the literature the effects of unanticipated idiosyncratic shocks which transmit across national borders are denoted as contagion; here these shocks originate in Russia and the U.S. 
The concept of contagion from both a theoretical and empirical viewpoint is controversial in the literature. Recent overviews of the issues are provided by Rudi Dornbusch, Yung Park and Stijn Claessens (2000) and Marcello Pericoli and Massimo Sbracia (2001). The definition of contagion adopted in this paper is that contagion reflects the spillover effect of unanticipated contemporaneous shocks across countries. This is similar to concepts expressed by Carlo Favero and Francesco Giavazzi (2000) and Forbes and Rigobon (2000, 2002). In contrast, Eichengreen, Rose and Wyplosz (1996) and Renato Reside and Maria Gochoco-Bautista (1999), base their view of contagion on the spillover effects of anticipated shocks across countries.

Contagion viewed as unanticipated, or as a residual, is a common theme in the literature, for example the work of Sachs, Tornell and Velasco (1996) and Masson (1999a,b,c). Masson decomposes exchange rate changes into three components. These are "monsoonal shocks", or global shocks affecting all countries simultaneously, equivalent to $W_{t}$ in (7); spillovers, which occur through normal trade and economic relationships, and a residual, which is the component unexplained by these systematic relationships. It is this concept that both Masson and we denote as contagion.

Masson (1999a,b,c) attributes part of the residual process to multiple equilibria, or sunspots, where there is a role for self-fulfilling expectations leading to contagion if opinions are coordinated across countries, an approach also taken by Olivier Loisel and Philippe Martin (2001). Multiple equilibria models are also consistent with other channels for contagion, such as wake-up calls due to Goldstein (1998) or heightened awareness due to Lowell, Neu and Tong (1998). In these cases a reappraisal of one country's fundamentals leads to a reappraisal 
of fundamentals in other countries, thereby resulting in the transmission of crises. Albert Kyle and Wei Xiong (2001) explain contagion in the LTCM and Russian crises as a wealth effect, as traders trading in risky markets encounter unanticipated shocks and liquidate across their portfolios. Thus, a shock in one market can reverberate in seemingly unconnected markets. Both the wake-up call, wealth effect model and Masson's definition of contagion are consistent with the model presented in Section II as long as there is no anticipation of the event.

The transmission of expectations in both the multiple equilibrium and wake-up call models can lead to herd behavior as in work by Graciela Kaminsky and Sergio Schmukler (1999) and Guillermo Calvo and Enrique Mendoza (2000). Herd behavior leads to a concept distinguished as unwarranted contagion by Mark Kruger, Patrick Osakwe and Jennifer Page (1998), which occurs when a crisis spreads to another country that otherwise would not have experienced a speculative attack. This is also corresponds with contagion defined as a residual. A further potential channel of contagion is through asset bubbles created by selffulfilling expectations, moral hazard, or government guarantees, either implied or explict. Paul Krugman (1998) shows how herd behaviour may burst these bubbles.

Existing empirical work which also uses definitions of contagion fitting into the current framework include Forbes and Rigobon (2002) who look for changes in the correlation structure between asset returns and Favero and Giavazzi (2000) who examine unexpected shock transmission. The effect of 'news' announcements in transmitting crises is investigated by Taimur Baig and Ilan Goldfajn (1999) and Luci Ellis and Eleanor Lewis (2000) for a range of countries. Kaminsky and Schmukler (1999) also analyze the effects of news, where 
contagion is defined as the spread of investors' moods across national borders. Their key result is that some of the largest swings in the stock market occurred on days of no news. However, Baig and Goldfajn (1999) and Kaminsky and Schmukler (1999) make no distinction between anticipated or unanticipated news.

Alternative definitions of contagion which lie outside the framework adopted in this paper are based on anticipated spillovers. In the framework of Section III, these channels would be captured by the global and regional factors of the model. For example, Reside and GochocoBautista (1999) define contagion as the spillover effects of domestic disturbances on nearby or related economies, using lagged changes in the exchange rates as their contagion variable, while Morris Goldstein, Graciela Kaminsky and Carmen Reinhart (2000) construct a contagion vulnerability index based on correlations between stock markets, trade linkages, presence of common markets and inter-linkages between banking systems. Caroline Van Rijckeghem and Beatrice Weder (2001) construct a subjective binary variable to examine contagion effects due to financial and trade linkages. Eichengreen, Rose and Wyplosz (1996), Tony Wirjanto (1999), and Kruger, Osakwe and Page (1998) condition their models on the existence of a crisis elsewhere, which implies that volatility is anticipated.

The factor model developed in Section III is able to encompass many of the existing definitions of contagion in the literature. In particular it brings a focus on the importance of two aspects of contagion, that it be unanticipated and transmitted across borders. The next Section briefly exposits the estimation methodology and Section VI presents estimates of the extent of contagion in the twelve countries described in Section II. 


\section{Estimation Method}

Christian Gourieroux and Alan Monfort (1994) have shown that direct estimation of the factor model in Section III by likelihood methods is infeasible as a result of the nonlinearisation arising from the $\mathrm{GARCH}$ conditional variance structure. Estimation procedures based on the Kalman filter or GMM only produce an approximation to the likelihood and thereby yield inconsistent parameter estimates. To circumvent problems of parameter inconsistency we adopt indirect estimation techniques to estimate the models specified in Section III. Indirect estimation belongs to a class of techniques which match the characteristics of the sample data with those of data simulated from the hypothesized model to obtain the parameter estimates. The key to this technique is that while the model is analytically complex to evaluate directly, it is relatively straightforward to simulate. Other forms of this technique are known as Simulated Method of Moments (SMM) and Efficient Method of Moments (EMM). SMM is associated with the work of Darrell Duffie and Ken Singleton (1993), EMM with Ron Gallant and George Tauchen (1996) and Indirect Inference with Christian Gourieroux, Alan Monfort and Eric Renault (1993) and Gourieroux and Monfort (1994). The differences between the three methods lie in the way in which the matching between actual and simulated data proceeds.

The matching of moments is accomplished via specifying an auxiliary model which acts as an approximation to the true likelihood function. The auxiliary model specified here consists of five components, which are designed to capture the key empirical characteristics of the data. The first set of conditions is based on a VAR(1) of the levels of the premiums, where 
the moments are given by the product of the residuals and the lagged values of all premiums in the VAR, $P_{t-1}$. That is,

$$
k_{t}^{0}=\left\{u_{1 t} P_{t-1}^{\prime}, u_{2 t} P_{t-1}^{\prime}, u_{3 t} P_{t-1}^{\prime}, \ldots u_{12 t} P_{t-1}^{\prime}\right\}
$$

This is of dimension (1x144).

The second set of moment conditions corresponds to the variance of the level of the premiums. Formally,

$$
k_{t}^{1}=P_{i, t}^{2}, \quad i \geq 1,2, \ldots, 12
$$

The third set of moment conditions captures the AR(1) structure of the changes in the premiums,

$$
k_{t}^{2}=\left(\Delta P_{i, t}-\Delta \bar{P}_{i, t}\right)\left(\Delta P_{i, t-1}-\Delta \bar{P}_{i, t-1}\right), \quad i=1,2, \ldots 12
$$

The fourth and fifth set of moment conditions capture conditional volatility in the premiums arising from the GARCH characteristics of the data identified in Section II. It comprises $\mathrm{AR}(1)$ and $\mathrm{AR}(2)$ loadings for the squared changes in the premiums. In a similar manner to Diebold and Nerlove (1989), the number of overidentifying conditions is controlled by including only the 'own' squared autocorrelations of the change in the premium. The corresponding vectors of conditions for the auxiliary model contain a total of 12 elements each

$$
\begin{aligned}
& k_{t}^{3}=\left(\Delta P_{i, t}^{2}-\Delta \bar{P}_{i, t}^{2}\right)\left(\Delta P_{i, t-1}^{2}-\Delta \bar{P}_{i, t-1}^{2}\right), \quad i=1,2, \ldots, 12, \\
& k_{t}^{4}=\left(\Delta P_{i, t}^{2}-\Delta \bar{P}_{i, t}^{2}\right)\left(\Delta P_{i, t-2}^{2}-\Delta \bar{P}_{i, t-2}^{2}\right), \quad i=1,2, \ldots, 12 .
\end{aligned}
$$

Collecting all $(144+12+12+12+12)$ time series from (9) to (13) into the $(1 \times 192)$ vector 


$$
g_{t}=\left\{k_{t}^{0}, k_{t}^{1}, k_{t}^{2}, k_{t}^{3}, k_{t}^{4}\right\}
$$

defines all of the moment conditions that summarize the auxiliary model at time $t$.

Analogous to the moment conditions based on the sample data, a set of moment conditions based on the simulated data is given by,

$$
v_{h}=\left\{k_{h}^{0}, k_{h}^{1}, k_{h}^{2}, k_{h}^{3}, k_{h}^{4}\right\}
$$

where $k_{h}^{0}, k_{h}^{1}, k_{h}^{2}, k_{h}^{3}$ and $k_{h}^{4}$ are the analogs of equations (9) to (13) with the actual data replaced by the simulated data for the $h^{\text {th }}$ simulation of the premium, $P_{i, h}$.

Letting $\theta$ be the set of unknown parameters of the latent factor model, the indirect estimator, $\hat{\theta}$, is the solution of:

$$
\hat{\theta}=\underset{\theta}{\arg \min }\left[\bar{g}-\frac{1}{H} \sum_{h=1}^{H} \bar{v}_{h}\right]^{\prime} \Omega^{-1}\left[\bar{g}-\frac{1}{H} \sum_{h=1}^{H} \bar{v}_{h}\right],
$$

where $\bar{g}$ and $\bar{v}_{h}$ are respectively the sample means of equations (14) and (15). The matrix $\Omega$ is a weighting matrix computed as follows (see Gourieroux, Monfort and Renault (1993)) with Newey-West weights

$$
\begin{aligned}
& \Omega=\frac{1}{T} g_{t}^{\prime} g_{t}+\frac{1}{T} \sum_{l}^{L} \omega_{l}\left(g_{t}^{\prime} g_{t-l}+g_{t-l}^{\prime} g_{t}\right) \\
& \text { with } \omega_{l}=1-\frac{1}{L+1} .
\end{aligned}
$$

In constructing this weighting matrix, the blocks are assumed to be independent. 
The indirect estimator in equation (16) is solved using the standard gradient algorithms from OPTMUM in GAUSS version 3.2, where the gradients are computed numerically. The simulations are based on normal random numbers from the GAUSS procedure RNDN. ${ }^{8}$

\section{EMPIRICAL RESULTS}

To examine the differences between the transmission of contagion from the Russian crisis and the LTCM near-collapse the model's unconditional variance decomposition specified in equation (8) is presented in Table 1. ${ }^{9}$ Total volatility is decomposed into the contribution due to the world factor, regional factors, country-specific factors and the contagion effects from Russia and the LTCM. Reiterating, contagion is said to exist if the unanticipated shocks from Russia or the U.S. spillover to volatility in the premiums of the other countries in the sample. The unanticipated shocks are measured by the inclusion of the country-specific factors for Russia and the U.S. in the premium equations of the other countries. The unconditional

\footnotetext{
${ }^{8}$ All results are based on 500 simulation paths with a convergence tolerance of 0.001 and a lag window of $L=5$ in equation (18) .

${ }^{9}$ Experiments extending this class of model to allow for contagion from the Latin American and Asian regions in conjunction with contagion from the U.S. and Russia were undertaken to allow for the most general specification. However, this line of research was not pursued due to an undesirable amount of parameter instability inherent in the larger models. Further, in Dungey, Fry, González-Hermosillo and Martin (2002), the model was originally estimated to allow for contagion effects from Russia only and was then augmented to include the effects from the LTCM crisis.
} 
volatility decompositions for the change in the premiums for each country are given in Table 1 and are summarized in Figure 3. ${ }^{10}$

\section{Table 1: Volatility Decomposition of Changes in the Premiums (contribution to total volatility, in percent)}

\begin{tabular}{lrrrrrr}
\hline & & & & \multicolumn{3}{c}{ Contagion } \\
\cline { 5 - 7 } & World & Country & Regional & $\begin{array}{c}\text { From } \\
\text { Russia }\end{array}$ & $\begin{array}{c}\text { From } \\
\text { U.S. }\end{array}$ & Total \\
\cline { 5 - 7 } Industrial & & & & & & \\
U.S. & 84.972 & 11.833 & - & 3.196 & - & 3.196 \\
U.K. & 99.735 & 0.013 & - & 0.099 & 0.153 & 0.252 \\
Netherlands & 82.289 & 0.520 & - & 16.941 & 0.251 & 17.191 \\
Eastern Europe & & & & & & \\
Russia & 94.733 & 5.058 & 0.107 & & 0.102 & 0.102 \\
Poland & 93.708 & 0.046 & 0.659 & 5.314 & 0.273 & 5.587 \\
Bulgaria & 91.334 & 0.204 & 0.516 & 7.573 & 0.374 & 7.946 \\
Asia & & & & & & \\
Indonesia & 98.847 & 0.269 & 0.205 & 0.299 & 0.381 & 0.679 \\
Korea & 88.853 & 4.950 & 0.880 & 1.571 & 3.746 & 5.317 \\
Thailand & 90.521 & 1.318 & 0.376 & 6.181 & 1.603 & 7.784 \\
Latin America & & & & & & \\
Mexico & 99.736 & 0.001 & 0.006 & 0.148 & 0.109 & 0.257 \\
Argentina & 86.828 & 12.676 & 0.045 & 0.352 & 0.099 & 0.451 \\
Brazil & 83.153 & 0.184 & 0.004 & 16.410 & 0.249 & 16.659 \\
& & & & & & \\
\hline
\end{tabular}

10 The volatility decomposition presented here corresponds to estimating the model, and allowing for contagion from Russia to other countries, over the entire sample period. However, contagion from the LTCM to other countries was constrained to occur only for that part of the sample during which the LTCM crisis was in effect (September 23 to October 15, when the indicator variable I for the U.S. is set equal to one, as discussed in Section IV). The volatility decomposition excluding the LTCM crisis period (where the indicator variable I is set equal to zero) was also calculated. However, since the contagion effects from the LTCM crisis to the other countries are relatively small, the volatility decomposition results are very similar in both cases and the latter are not reported here (available from the authors upon request). 
Figure 3: Volatility Decomposition of Changes in the Premiums (contribution to total volatility, in percent)

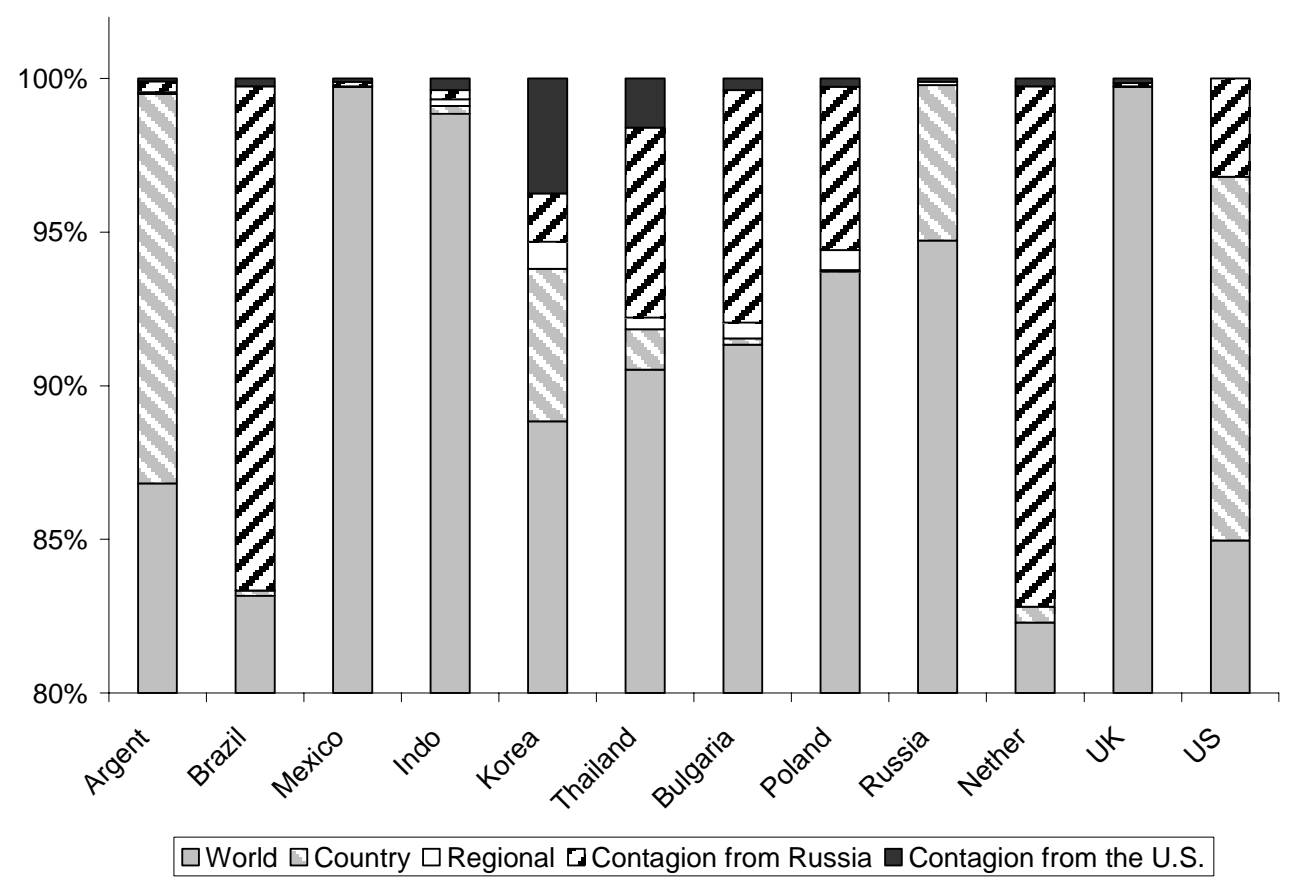

The results in Table 1 indicate that the dominant factor in the volatility decomposition of the change in the bond premiums is the world factor, pointing strongly towards commonality in the movements in premiums experienced over the sample period (figures 1 and 2). This result is consistent with the view that increasing financial market integration has led to high (and expected) co-movements in asset prices. The world factor accounts for between 82 percent (Netherlands) and 99.7 percent (U.K. and Mexico) of total volatility. A corollary of this is that the regional factors have little influence on volatility, with all accounting for less than one percentage point of total volatility. Country-specific factors are relatively important for the U.S. and Argentina, and to a lesser extent Russia and Korea, but in each case account for no more than 13 percent of total volatility. 
Table 1 shows that most of the contagion effects in the results are sourced from Russia. Contagion affects a wide range of countries across the regions investigated. From the industrial nations, the Netherlands experienced almost 17 percent of total volatility due to contagion from Russia. Other developed markets experienced less than 4 percent. The next largest effects were felt in Latin America, where contagion from Russia accounted for 16 percent of volatility in Brazil, although less than 1 percent in the other Latin American economies. Unsurprisingly, the region which experienced the most consistent contagion effect across countries is Eastern Europe, where contagion from Russia represents 5 and 7 percent of volatility for Poland and Bulgaria respectively. In Asia, Russian contagion effects range between 6 percent for Thailand to less than 1 percent for Indonesia.

In contrast, contagion from the LTCM shock is very small as a proportion of total volatility, although it was also widespread across countries and regions. The largest contagion effect from the LTCM shock is under 4 percent of total volatility, experienced by Korea. It is possible that the relatively small LTCM effects are the result of the coordinated action of the U.S. Fed to halt its spread.

Contagion from Russia to the US accounted for about 3 percent of total volatility in the US, while contagion from the LTCM crisis to Russia was small at less than 0.2 percent of total volatility in Russia.

The results for Indonesia, Brazil, and Argentina are worthy of further examination. Indonesia drew comment as the hardest hit by contagion effects in currency markets during the 1997 Asian crisis; see for example discussions by Steven Radelet and Jeffrey Sachs (1998) and 
Goldstein, Kaminsky and Reinhart (2000). However, the contagion effects in Indonesian bond markets during 1998, as measured here, are relatively small. One hypothesis consistent with these results is that Indonesia had become extremely sensitive to global financial events in general by this stage, so that to some extent it had lost its 'immunity' to unanticipated shocks. Alternatively, contagion may have been transmitted through asset markets other than the bond market, possibly due to illiquidity in the Indonesian sovereign bond market during this time characterized by political turmoil in Indonesia. Disentangling these hypotheses is scope for future work.

The Brazilian results show a relatively large proportionate effect of contagion, supporting the view advanced by Taimur Baig and Ilan Goldfajn (2000) that the Russian crisis precipitated the Brazilian crisis of January 1999. The relatively large contagion effect to Brazil may be a reflection of the vulnerability of Brazil.

Argentina experienced relatively small contagion effects in 1998, which may come as a surprise given that it experienced a crisis a few years later. However, it is noteworthy that the factors determining total volatility in Argentina are different than the other countries in our sample, except for the U.S.. In particular, the contribution to total volatility coming from the country-specific factor is the largest. This may reflect the fact that Argentina was the only emerging economy in our sample with a currency board regime that appeared to be credible cduring this time. This may have made Argentina less sensitive to contagion and speculative attacks, given that the monetary base was fully backed by foreign reserves. 
The results provide little evidence to support the hypothesis that contagion emanating from Russia is confined to developing nations, or that contagion emanating from LTCM was confined to developed markets - as suggested by the Bank for International Settlements (1999). However, it is difficult to derive any stylized facts to support or refute the contention that developing markets are more affected by contagion than developed markets. Not only is there evidence that contagion affects both developed and developing markets, but other evidence similarly indicates that there are some developing and developed markets in our sample which are not affected by contagion. Countries that are little affected by the Russian shock, with less than one percentage point of total volatility attributed to contagion, include the U.K., Mexico, Argentina and Indonesia.

To address these issues further, we transform the results in Table 1 into their squared basis point equivalent by multiplying the values in Table 1 by the variance in the changes in the premiums for each country (i.e. the square of the standard deviations which are reported in Table II.2 in Appendix II). The variance decomposition in squared basis points is reported in Table 2.

Comparing the results in Tables 1 and 2 highlights the differences between developing and developed markets. In proportionate terms the Netherlands experienced the greatest contribution from contagion during this period, at around 17 percent, while in squared basis point terms the volatility was relatively low, only greater than the other developed markets and Mexico. On the other hand, Brazil, which had the second greatest proportionate contribution from contagion, also has the second greatest basis point contribution, at around 590 squared basis points. The largest squared basis point contribution from contagion was 
experienced by Bulgaria. Bulgaria had a proportionate contribution from contagion of almost 8 percent, similar to that for Thailand, but contagion contributed 795 squared basis points in Bulgaria, compared with 39 squared basis points in Thailand. Developing countries experience a greater basis point contribution from contagion than the developed countries due to their absolute higher levels of volatility. However, in proportionate terms contagion effects do not clearly differentiate between developed and developing markets.

Table 2: Volatility Decomposition of Changes in the Premiums (contribution to total volatility, in squared basis points)

\begin{tabular}{|c|c|c|c|c|}
\hline & World & Country & Regional & $\begin{array}{c}\text { Total } \\
\text { Contagion }\end{array}$ \\
\hline \multicolumn{5}{|l|}{ Industrial } \\
\hline U.S. & 6.380 & 0.888 & - & 0.240 \\
\hline U.K. & 13.876 & 0.002 & - & 0.035 \\
\hline Netherlands & 23.907 & 0.151 & - & 4.994 \\
\hline \multicolumn{5}{|c|}{ Eastern Europe } \\
\hline Russia & 55685.890 & 2973.197 & 62.971 & 59.942 \\
\hline Poland & 494.421 & 0.245 & 3.479 & 29.476 \\
\hline Bulgaria & 9138.896 & 20.378 & 51.620 & 795.107 \\
\hline \multicolumn{5}{|l|}{ Asia } \\
\hline Indonesia & 3085.454 & 8.385 & 6.408 & 21.210 \\
\hline Korea & 728.813 & 40.602 & 7.219 & 43.616 \\
\hline Thailand & 452.579 & 6.591 & 1.882 & 38.918 \\
\hline \multicolumn{5}{|c|}{ Latin America } \\
\hline Mexico & 525.311 & 0.006 & 0.034 & 1.352 \\
\hline Argentina & 984.339 & 143.707 & 0.505 & 5.118 \\
\hline Brazil & 2923.097 & 6.472 & 0.138 & 585.600 \\
\hline
\end{tabular}

\section{CONCLUSION}

The international spillover effects stemming from the Russian debt default and the nearcollapse of LTCM in 1998 seemed to be different from those of other financial crises in the 
1990s. In 1998, bond markets in both advanced and emerging economies experienced a significant widening of spreads between long-term bonds and their corresponding risk-free rate of return, or the 'premium.' In other episodes of financial crises during the 1990s, most of the impact seemed to be limited to emerging markets or even a regional subset of them.

This paper examined the crises associated with the Russian bond default in August 1998, and the near-collapse of LTCM in September 1998. Using a latent factor model, the change in the premiums of twelve markets is decomposed into components associated with a common world factor, country-specific factors, regional factors and contagion effects. Contagion is defined as the contemporaneous effect of unanticipated shocks transmitted across country borders. This definition of contagion is consistent with those offered in a substantial portion of the literature on this topic, including Masson (1999a,b,c), Favero and Giavazzi (2000), and Forbes and Rigobon $(1999,2000)$. The novelty of this paper is both in the application to bond markets and that we provide numerical estimates of the contribution of contagion to volatility in those markets.

The key issues analyzed in this paper are as follows. First, whether there is evidence of contagion in the crises period; second, whether developing countries are more affected by contagion than industrial countries; and, relatedly, whether the hypothesis that the Russian collapse affected mainly developing markets while the LTCM near-collapse mainly developed markets is supported in the data.

The results show clear evidence of contagion effects from Russia, to both developing and developed countries, while the global contagion effects from the LTCM were smaller. In 
proportionate terms, contagion effects from Russia were particularly substantial for the Netherlands, Brazil, Bulgaria and Thailand. Contagion effects in those countries ranged from 8 percent to about 17 percent of total volatility. The absence of meaningful contagion from the LTCM near-collapse, as a global liquidity shock, is somewhat surprising given the anecdotal evidence offered by traders surveyed by the Bank for International Settlements (1999). However, these results may reflect the short duration of the LTCM crisis (spanning about three weeks) as the Fed acted to contain a potential credit crunch by easing monetary policy aggressively. The evidence also suggests that while the U.S. experienced some contagion from Russia, contagion from the LTCM crisis to Russia was very small.

The proportion of volatility in the premiums attributed to contagion did not provide clear evidence as to whether the crises had a greater effect on developing or developed markets. When the results are transformed to squared basis point effects, the evidence generally supports the contention that contagion is greater in developing markets, due to the overall higher degree of volatility typically experienced in those markets. While most of the literature on contagion generally espouses the notion that contagion is only a concern for developing countries, the results in this paper suggest that contagion can also be meaningful for developed economies.

Our results also give support to the view that Brazil was affected by contagion prior to its currency crisis in January 1999. The relatively large contagion effects to Brazil may be a reflection of the vulnerability of this country. This hypothesis provides scope for interesting future work in establishing at what point pre-crisis jitters are evident in financial markets. 


\section{References}

Bae, Kee-Hong; Karyoli, George A. and Stulz, Rene M. "A New Approach to Measuring Financial Contagion." National Bureau of Economic Research (Cambridge, MA) Working Paper No. 7913, September 2000.

Baig, Taimur and Goldfajn, Ilan. "Financial Market Contagion in the Asian Crisis." International Monetary Fund Staff Papers, June 1999, 46(2), pp.167-195.

Baig, Taimur and Goldfajn, Ilan. "The Russian Default and the Contagion to Brazil." International Monetary Fund Working Paper WP/00/160, October 2000.

Bank for International Settlements, Committee on the Global Financial System. A Review of Financial Market Events in Autumn 1998. Basel, Switzerland, October 1999.

Calvo, Guillermo A. and Mendoza, Enrique G. "Rational Contagion and the Globalization of Securities Markets.” Journal of International Economics, June 2000, 51(1), pp. 79-113.

Diebold, Francis X. and Nerlove, Marc. "The Dynamics of Exchange Rate Volatility: A Multivariate Latent-Factor ARCH Model.” Journal of Applied Econometrics, January March 1989, 4(1), pp. 1-22.

Dooley, Michael P. “A Model of Crises in Emerging Markets.” Economic Journal, 2000, 110(460), pp. 256-72.

Dornbusch, Rudiger; Park, Yung C. and Claessens, Stijn. "Contagion: Understanding How It Spreads.” World Bank Research Observer, August 2000, 15(2), pp. 177-97.

Duffie, Darrell and Singleton, Kenneth. "Simulated Moments Estimator of Markov Models of Asset Prices.” Econometrica, July 1993, 61(4), pp. 929-62.

Dungey, Mardi; Fry, Renée; González-Hermosillio, Brenda and Martin, Vance L. "International Contagion Effects from the Russian Crisis and the LTCM Near Collapse." International Monetary Fund Working Paper WP/02/74, April 2002.

Dungey, Mardi; Martin, Vance L. and Pagan, Adrian R. "A Multivariate Latent Factor Decomposition of International Bond Yield Spreads." Journal of Applied Econometrics, November - December 2000, 15(6), pp. 697-715.

Edwards, Sebastian. "Interest Rates, Contagion and Capital Controls." National Bureau of Economic Research (Cambridge, MA) Working Paper No. 7801, July 2000. 
Eichengreen, Barry; Rose, Andrew K. and Wyplosz, Charles. "Exchange Market Mayhem: The Antecedents and Aftermath of Speculative Attacks." Economic Policy, October 1995, 21, pp. 249-312.

Eichengreen, Barry; Rose, Andrew K. and Wyplosz, Charles. "Contagious Currency Crises." National Bureau of Economic Research (Cambridge, MA) Working Paper No. 5681, July 1996.

Ellis, Luci and Lewis, Eleanor. "The Response of Financial Markets in Australia and New Zealand to News about the Asian Crisis." BIS Conference on International Financial Markets and the Implications for Monetary and Financial Stability, Basle, 25-26 October 1999, Vol.8.

Favero, Carlo A. and Giavazzi, Francesco. "Looking for Contagion: Evidence from the ERM." National Bureau of Economic Research (Cambridge, MA) Working Paper No. 7797, July 2000.

Forbes, Kristin and Rigobon, Roberto. "Measuring Contagion, Conceptual and Empirical Issues.” Mimeo, Massachusetts Institute of Technology, 2000.

Forbes, Kristin and Rigobon, Roberto. "No Contagion, Only Interdependence: Measuring Stock Market Co-Movements." Journal of Finance, October 2002, forthcoming.

Gallant, A. Ronald and Tauchen, George. "Which Moments to Match?" Econometric Theory, October 1996, 12 (4), pp. 657-81.

Glick, Reuven and Rose, Andrew K. "Contagion and Trade: Why are Currency Crises Regional?” Journal of International Money and Finance, August 1999, 18(4), pp. 60317.

Goldstein, Morris. "The Asian Financial Crisis: Causes, Cures and Systemic Implications." Policy Analysis in International Economics, 55, Institute for International Economics, Washington D.C., June 1998.

Goldstein, Morris; Kaminsky, Graciela L. and Reinhart, Carmen M. "Assessing Financial Vulnerability: An Early Warning System for Emerging Markets." Institute for International Economics, Washington D.C., 2000.

Gourieroux, Christian and Monfort, Alain. "Simulation Based Econometric Methods" CORE Discussion Paper, 1994.

Gourieroux, Christian; Monfort, Alain and Renault, Eric. "Indirect Inference." Journal of Applied Econometrics, December 1993, 8, S85-S118. 
Gregory, Allan W. and Watts, David G. "Sources of Variation in International Real Interest Rates." Canadian Journal of Economics, November 1995, 28, S120-S140.

Jorion, Philippe. "Risk Management Lessons from Long-Term Capital Management." European Financial Management, September 2000, 6, pp. 277-300.

Kaminsky, Graciela L. and Reinhart, Carmen M. "On Crises, Contagion and Confusion." Journal of International Economics, June 2000, 51(1), pp. 145-68.

Kaminsky, Graciela L. and Reinhart, Carmen M. "The Center and the Periphery: The Globalization of Financial Turmoil", paper presented at the Third Joint Central Bank Research Conference on Risk Measurement and Systemic Risk, 7-8 March 2002, BIS, Basel, Switzerland.

Kaminsky, Graciela L. and Schmukler, Sergio L. "What Triggers Market Jitters? A Chronicle of the Asian Crisis." Journal of International Money and Finance, August 1999, 18(4), pp. 537-60.

Kharas, Homi; Pinto, Brian and Ulatov, Sergei. "An Analysis of Russia's 1998 Meltdown: Fundamentals and Market Signals.” Brookings Papers on Economic Activity, 2001, (1), pp.1-68.

King, Mervyn; Sentana, Enrique and Wadhwani, Sushil. "Volatility and Links Between National Stock Markets.” Econometrica, July 1994, 62(4), pp. 901-33.

Kose, Ayhan M.; Otrok, Christopher and Whiteman, Charles H. "International Business Cycles: World, Region and Country-Specific Factors." Manuscript, University of Iowa, 1999.

Kruger, Mark; Osakwe Patrick N. and Page, Jennifer. "Fundamentals, Contagion and Currency Crises: An Empirical Analysis.” Bank of Canada (Ottawa, Ontario) Working Paper No. 98-10, July 1998.

Krugman, Paul. "What Happened to Asia?" Mimeo, Massachusetts Institute of Technology, 1998.

Kumar, Manmohan and Avinash Persaud. "Pure Contagion and Investors' Shifting Risk Appetite: Analytical Issues and Empirical Evidence." International Monetary Fund Working Paper WP/01/134, September 2001.

Kyle, Albert S. and Wei Xiong. "Contagion as a Wealth Effect" Journal of Finance, 2001, LVI(4), pp. 1401-1440. 
Loisel, Olivier and Martin, Philippe. "Coordination, Cooperation, Contagion and Currency Crises.” Journal of International Economics, April 2001, 53(2), pp. 399-419.

Lowell, Julia; Neu, C. Richard and Tong, Daochi. "Financial Crises and Contagion in Emerging Market Countries.” RAND, MR-962, 1998.

Mahieu, Ronald and Schotman, Peter. "Neglected Common Factors in Exchange Rate Volatility.” Journal of Empirical Finance, July 1994, 1(3-4), pp. 279-311.

Masson, Paul. "Contagion: Macroeconomic Models With Multiple Equilibria." Journal of International Money and Finance, August 1999, 18(4), pp. 587-602.

. "Contagion: Monsoonal Effects, Spillovers, and Jumps Between Multiple Equilibria," in Pierre-Richard Agenor, Marcus Miller, David Vines, and Axel Weber, eds., The Asian Financial Crisis: Causes, Contagion and Consequences. Cambridge, U.K.: Cambridge University Press, 1999, pp. 265-283.

- "Multiple Equilibria, Contagion and the Emerging Market Crises." International Monetary Fund Working Paper WP/99/164, December 1999.

Ng, Victor K.; Engle, Robert F. and Rothschild, Micheal. "A Multi-Dynamic Factor Model for Stock Returns.” Journal of Econometrics, April - May 1992, 52(1-2), pp. 245-66.

Pericoli, Marcello and Sbracia, Massimo. “A Primer on Financial Contagion.” Banca D'Italia Termi di Discussione \#407, (Economic Research Discussion Papers), June 2001.

Radelet, Steven and Sachs, Jeffrey. "The Onset of the East Asian Financial Crisis." Mimeo, Harvard Institute for International Development, 1998.

Reside Jr, Renato E. and Gochoco-Bautista, Maria S. "Contagion and the Asian Currency Crisis." The Manchester School, month? 1999, 67(5), pp. 460-74.

Sachs, Jeffrey; Tornell, Aaron and Velasco, Andrés. "Financial Crises in Emerging Markets: The Lessons from 1995." Brookings Papers on Economic Activity, 1996, (1), pp. 146215.

Van Rijikeghem, Caroline and Weder, Beatrice. "Sources of Contagion: Is it Finance or Trade?” Journal of International Economics, August 2001, 54(2), pp. 293-300.

Wirjanto, Tony S. "Empirical Indicators of Currency Crises in East Asia." Pacific Economic Review, June 1999, 4(2), pp. 165-83. 


\section{A. Data Definitions and Sources}

Argentina: Republic of Argentina bond spread over U.S. Treasury. Source: U.S. Federal Reserve.

Brazil: Republic of Brazil bond spread over U.S. Treasury. Source: U.S. Federal Reserve.

Mexico: JP Morgan Eurobond Index Mexico Sovereign spread over U.S. Treasury. Source: U.S. Federal Reserve.

Indonesia: Indonesian Yankee Bond Spread over U.S. Treasury. Source: U.S. Federal Reserve.

Korea: Government of Korea 8 7/8\% 4/2008 over U.S. Treasury. Source: Bloomberg (50064FAB0)

Thailand: Kingdom of Thailand Yankee Bond Spread over U.S. Treasury. Source: U.S. Federal Reserve. (The longer series used in Figure 1, 7.75\% 15/04/07, comes from Credit Swiss First Boston).

Bulgaria: Bulgarian Discount Stripped Brady Bond Yield Spread over U.S. Treasury. Source: U.S. Federal Reserve.

Poland: Poland Par Stripped Brady Bond Yield Spread over U.S. Treasury. Source: U.S. Federal Reserve.

Russia: Government of Russia 9.25\% 11/2001 over U.S. Treasury. Source: Bloomberg (007149662).

Netherlands: Akzo Nobel NV 8\% 12/2002 yield spread over NETHER 8.25\% 6/2002. Source: U.S. Federal Reserve.

U.K.: U.K. Industrial BBB Corporate 5-year Bond Spread over Gilt. Source: Bloomberg (UKBF3B05)

U.S.: U.S. Industrial BBB1 Corporate 10-year Bond Spread over U.S. Treasury. Source: Bloomberg (IN10Y3B1)

The estimation is based on daily data on spreads from February 12 to January 1, 1999. The bond spreads, or "risk premiums," are constructed by taking a representative long-term sovereign bond issued in U.S. dollars by an emerging country and subtracting from it a U.S. Treasury bond of comparable maturity. For advanced economies, the risk premiums are constructed by taking a representative long-term corporate bond in domestic currency and subtracting from it a government Treasury bond of comparable maturity.

Missing observations were dealt with by removing all contemporaneous observations for that date across countries. The original sample of 231 observations was reduced to 209 observations after accounting for missing observations. The exact details of the missing observations are contained in Dungey, Fry, GonzalezHermosillo and Martin (2002). 
Table II.1: Descriptive Statistics of Premiums (in levels)

\begin{tabular}{|c|c|c|c|c|c|c|}
\hline \multirow[b]{2}{*}{ Statistic } & \multicolumn{3}{|c|}{ Industrial Countries } & \multicolumn{3}{|c|}{ Eastern Europe } \\
\hline & U.S. & U.K. & Netherlands & Russia & Poland & Bulgaria \\
\hline Mean & 106.06 & 122.92 & 58.59 & 2871.81 & 261.21 & 951.72 \\
\hline Maximum & 153.00 & 203.00 & 109.10 & 6825.78 & 521.00 & 2279.00 \\
\hline Minimum & 67.00 & 76.00 & 34.20 & 392.35 & 162.00 & 535.00 \\
\hline Std. Dev. & 28.85 & 36.26 & 20.38 & 2512.65 & 75.73 & 431.92 \\
\hline $\operatorname{AR}(1)$ & 0.99 & 0.99 & 0.96 & 0.99 & 0.95 & 0.97 \\
\hline $\operatorname{AR}(2)$ & 0.98 & 0.98 & 0.93 & 0.98 & 0.90 & 0.94 \\
\hline Skewness & 0.44 & 0.72 & 0.95 & 0.28 & 0.95 & 1.35 \\
\hline Kurtosis & 1.38 & 2.03 & 2.42 & 1.20 & 3.17 & 4.26 \\
\hline \multirow[t]{3}{*}{$\begin{array}{l}\text { Jarque-Bera } \\
\text { (p value) }\end{array}$} & $\begin{array}{r}29.51 \\
(0.000)\end{array}$ & $\begin{array}{r}26.11 \\
(0.000)\end{array}$ & $\begin{array}{r}34.24 \\
(0.000)\end{array}$ & $\begin{array}{r}30.96 \\
(0.000)\end{array}$ & $\begin{array}{r}31.53 \\
(0.000)\end{array}$ & $\begin{array}{r}77.52 \\
(0.000)\end{array}$ \\
\hline & \multicolumn{3}{|l|}{ Asia } & \multicolumn{3}{|c|}{ Latin America } \\
\hline & Indonesia & Korea & Thailand & Mexico & Argentina & Brazil \\
\hline Mean & 959.67 & 486.26 & 423.17 & 469.70 & 534.70 & 744.07 \\
\hline Maximum & 1865.80 & 965.88 & 916.30 & 868.33 & 1061.00 & 1438.00 \\
\hline Minimum & 537.10 & 306.70 & 270.20 & 297.66 & 374.00 & 415.00 \\
\hline Std. Dev. & 369.50 & 163.88 & 167.48 & 155.61 & 140.62 & 291.13 \\
\hline $\operatorname{AR}(1)$ & 0.99 & 0.98 & 0.99 & 0.99 & 0.97 & 0.98 \\
\hline $\operatorname{AR}(2)$ & 0.97 & 0.96 & 0.98 & 0.97 & 0.94 & 0.96 \\
\hline Skewness & 0.97 & 1.26 & 1.16 & 0.66 & 1.26 & 0.61 \\
\hline Kurtosis & 2.58 & 3.84 & 3.32 & 2.16 & 4.38 & 2.12 \\
\hline Jarque-Bera & 34.05 & 61.44 & 47.79 & 21.10 & 71.84 & 19.71 \\
\hline ( $\mathrm{p}$ value) & $(0.000)$ & $(0.000)$ & $(0.000)$ & $(0.000)$ & $(0.000)$ & $(0.000)$ \\
\hline
\end{tabular}

Table II.2: Standard Deviations of the Change in the Premiums

\begin{tabular}{|c|c|c|c|}
\hline \multicolumn{2}{|c|}{ Industrial Countries } & \multicolumn{2}{|c|}{ Eastern Europe } \\
\hline U.S & 2.74 & Russia & 242.45 \\
\hline U.K & 3.73 & Poland & 22.97 \\
\hline Netherlands & 5.39 & Bulgaria & 100.03 \\
\hline Asia & & Latin Am & \\
\hline Indonesia & 55.87 & Mexico & 22.95 \\
\hline Korea & 28.64 & Argentina & 33.67 \\
\hline Thailand & 22.36 & Brazil & 59.29 \\
\hline
\end{tabular}


Table II.3: Augmented Dickey Fuller and Phillips Perron Unit Root Tests of the Premiums

\begin{tabular}{|c|c|c|c|c|c|c|}
\hline \multirow[b]{2}{*}{ Statistic } & \multicolumn{3}{|c|}{ Industrial Countries } & \multicolumn{3}{|c|}{ Eastern Europe } \\
\hline & U.S. & U.K. & Netherlands & Russia & Poland & Bulgaria \\
\hline $\begin{array}{l}\text { ADF Test } \\
\text { Phillips } \\
\text { Perron Test }\end{array}$ & $\begin{array}{l}-0.602 \\
-0.641\end{array}$ & $\begin{array}{l}-0.605 \\
-0.577\end{array}$ & $\begin{array}{l}-1.256 \\
-1.540\end{array}$ & $\begin{array}{l}-0.727 \\
-0.741\end{array}$ & $\begin{array}{l}-2.287 \\
-2.299\end{array}$ & $\begin{array}{l}-1.379 \\
-1.685\end{array}$ \\
\hline
\end{tabular}

Asia

$\longrightarrow$

\begin{tabular}{rrr} 
Indonesia & Korea & Thailand \\
\hline-1.219 & -1.302 & -1.129 \\
-1.216 & -1.433 & -1.081
\end{tabular}

Latin America

\begin{tabular}{lll}
\hline Mexico & Argentina & Brazil \\
& & \\
\hline-1.183 & -1.700 & -1.138 \\
-1.273 & -1.818 & -1.283
\end{tabular}

MacKinnon critical values for rejection of the hypothesis of a unit root for the ADF test are:

$1 \%$ critical value -3.4634 ( ${ }^{*}$ represents rejection at the $1 \%$ level of significance)

$5 \%$ critical value -2.8756 ( ${ }^{* *}$ represents rejection at the $5 \%$ level of significance)

Mackinnon critical values for rejection of the hypothesis of a unit root for the PP test are:

$1 \%$ critical value -3.4631 ( ${ }^{*}$ represents rejection at the $1 \%$ level of significance)

$5 \%$ critical value -2.8755 ( ${ }^{* *}$ represents rejection at the $5 \%$ level of significance) 
Table II.4 presents the results estimating a GARCH(1,1) model for changes in each of the premium series. The changes are examined in order to highlight the properties of the short-term adjustment process in the data.

$$
\begin{aligned}
& \Delta P_{i, t}=\rho_{0}+e_{i, t} \\
& e_{i, t}=\sqrt{h_{i, t}} u_{i, t} \\
& h_{i, t}=\alpha_{0}+\alpha_{1} e_{i, t-1}^{2}+\left(1-\alpha_{1}\right) h_{i, t-1} \\
& u_{i, t} \sim N(0,1),
\end{aligned}
$$

\begin{tabular}{|c|c|c|c|c|}
\hline \multirow[t]{2}{*}{ Country } & \multicolumn{3}{|c|}{ Parameter } & \multirow[b]{2}{*}{$\ln \mathrm{L}$} \\
\hline & $\rho_{0}$ & $\alpha_{0}$ & $\alpha_{1}$ & \\
\hline \multicolumn{5}{|l|}{ Industrials } \\
\hline \multirow[t]{2}{*}{ USA } & 0.061 & 1.059 & 0.595 & -467.876 \\
\hline & $(0.124)$ & $(1.320)$ & $(0.446)$ & \\
\hline \multirow[t]{2}{*}{ U.K. } & 0.070 & 1.627 & 0.409 & -553.957 \\
\hline & $(0.233)$ & $(0.776)$ & $(0.113)$ & \\
\hline \multirow[t]{2}{*}{ Netherlands } & -0.022 & 1.583 & 0.213 & -626.669 \\
\hline & $(0.322)$ & $(1.602)$ & $(0.144)$ & \\
\hline \multicolumn{5}{|c|}{ Eastern Europe } \\
\hline \multirow[t]{2}{*}{ Russia } & -0.022 & 1.584 & 0.213 & -636.669 \\
\hline & $(0.374)$ & $(1.609)$ & $(0.145)$ & \\
\hline \multirow[t]{2}{*}{ Poland } & -0.209 & 22.949 & 0.325 & -896.909 \\
\hline & $(0.902)$ & $(30.524)$ & $(0.254)$ & \\
\hline \multirow[t]{2}{*}{ Bulgaria } & 0.150 & 59.091 & 0.317 & -1088.000 \\
\hline & $(2.152)$ & $(37.833)$ & $(0.070)$ & \\
\hline \multicolumn{5}{|l|}{ Asia } \\
\hline \multirow[t]{2}{*}{ Indonesia } & -1.216 & 251.212 & 0.413 & -1088.470 \\
\hline & $(2.553)$ & $(212.662)$ & $(0.164)$ & \\
\hline \multirow[t]{2}{*}{ Korea } & -0.535 & 20.813 & 0.203 & -947.494 \\
\hline & $(1.212)$ & (11.063) & $(0.044)$ & \\
\hline \multirow[t]{2}{*}{ Thailand } & -0.700 & 32.425 & 0.250 & -906.889 \\
\hline & $(0.862)$ & $(30.407)$ & $(0.138)$ & \\
\hline \multicolumn{5}{|c|}{ Latin America } \\
\hline \multirow[t]{2}{*}{ Mexico } & 0.145 & 11.528 & 0.338 & -854.152 \\
\hline & $(0.649)$ & $(6.980)$ & $(0.098)$ & \\
\hline \multirow[t]{2}{*}{ Argentina } & 0.324 & 12.602 & 0.288 & -916.035 \\
\hline & $(0.897)$ & $(6.989)$ & $(0.065)$ & \\
\hline \multirow[t]{2}{*}{ Brazil } & 1.015 & 26.714 & 0.242 & -1023.260 \\
\hline & $(1.524)$ & (18.608) & $(0.055)$ & \\
\hline
\end{tabular}

where $\Delta P_{i, t}$ is the change in the premium for country $i$ recorded at time $t$.

Table II.4: Univariate GARCH (1,1) Parameter Estimates (QMLE standard errors in brackets) 